\title{
A Teaching and Learning Practice Incorporating Students' Own Goal and Their Institutional Goal in Big-Sized English Classes
}

\author{
Ari Nurweni \\ English Department \\ Lampung University \\ Bandarlampung, Indonesia \\ nurweniari@gmail.com
}

\begin{abstract}
This paper reports a study on a teaching and learning practice in three big-sized English classes incorporating the learning goal set by the students and that by their institution, which investigated three questions: 1) What do the students perceive at a text-based teaching and learning?; 2) What problems do the students face at the text-based teaching and learning class?; and 3) What do the students learn at the textbased teaching and learning? The subjects of this study were 208 first year students of a state engineering institute in Lampung, Sumatera, Indonesia. The 208 students were from 3 different classes. The teaching and learning activities were based on academic texts selected by the students in a group of ten. In every meeting a group of the students who had prepared a two-page English academic text presented its title and key words to the class, whereas the other groups asked questions based on the title and key words which had to be answered by the group orally. In every meeting at the end of the class the students were asked to write a journal according to the research questions. The results showed that they perceived the teaching and learning practice differently, they had some problems, but they learnt some linguistic elements and skills, and they realized that they still needed to improve their English skill as well as their participation in speaking.
\end{abstract}

Key words: big-sized English class, text-based English teaching and learning, perception

\section{INTRODUCTION}

At many Indonesian universities, English is a compulsory subject stated in their curriculum. The main goal of the subject is that the students are able to comprehend the contents of English texts relevant to their field of study. It is expected that the students are able to read English textbooks and journal articles which are used in their courses since reading relevant texts from various resources will widen and deepen their knowledge of the course contents. However, when I came to three parallel classes of a government engineering institute in Lampung, Indonesia and asked them what their goal of learning English was on the first meeting, they answered in chorus that they wanted to be able to speak English. These students' answer confirmed the previous studies conducted by Kern and Kumaravadivelu in Lixin (2005) that what EFL students' need is not always the same as what the teachers or the institution thinks [2].

That many students want to be able to speak English is understandable. Being able to speak English makes them feel proud since speaking ability is an indication of their overall English ability. Being able to speak English also allows them to take active participation in an international forum such as international seminars which are often held by their university or other universities by asking questions or giving comments. In addition, being able to speak English will help them later when they apply for a job which requires them to have an interview test in English. On the other hand, being able to read English texts is something which cannot be seen, and nowadays as technology advances to understand an English text they can rely on a translating tool, such as, google translate, which is handy through their smart handphone.

Understanding the students' needs will direct the teaching and learning process. Language teaching and learning will run effectively if it is able to satisfy the students' needs. The students will be more motivated to get involved in learning. Accordingly, the teaching and learning has to incorporate the students' goal and the one set by the institution. This means that the teaching and learning of English have to allow the students to speak in English as well as to direct the students to read English texts.

Text-based learning and teaching is likely to be able to serve the students and the institution to reach their goals. Textbased approach, which is one of approaches in language teaching, views a text as a base for language teaching and learning. In language teaching and learning texts can be viewed as a linguistic object (TALO), as a vehicle of information (TAVI) [10], and as a stimulus for production (TASP) [11]. As a linguistic object, texts are exploited to introduce linguistic elements such as vocabulary and syntactic patterns to the learners. Based on this view, the teachers will explain the sentence patterns and vocabulary found in the text which are the focus of their teaching.

As TAVI texts are processed in order to get the information from the text, to understand the content of the 
texts. TAVI leads the teachers to have the students to work on the text in a group [10]. They further states that group work provides enjoyful atmosphere for the students, provide opportunity for the students to have a real communication which may start by using their mother tongue, and through this the target language is gradually introduced to the sudents. Group work also provides a model of individual self study outside the classroom.

Whereas, viewing texts as a stimulus for production (TASP), the teachers use a text in language teaching as a base for another task that their students have to do [11]. For example, after reading a text provided by the teacher or selected by their group, the students then perform a role play, speak or discuss issues raised by the text, or write a response to the text. Reading the text is then not an end in itself. Based on their study, they come to a conclusion that factors which determine the effectiveness of text-based activities are students' knowledge of English, their awareness of text structure and organization, linguistic guess and quality of the tasks [11].

Mickan ellabotares the theoretical and practical reasons for selecting texts as a base in the teaching of reading. Firstly, teachers and students are familiar with language used in texts, whether as spoken dialogues or monologues. In daily life they are facing and producing texts even though it is not in the target language. Secondly, learners' familiarity with certain texts - their purposes and contexts of use-makes them familiar with the meaning of the text. Thirdly, texts allow the teacher and the students to use language for a real purpose. Fourth, teachers and students can select texts which are in accordance with their objectives of learning English. Fifth, texts are accessible for reading, for action, and for information at all age levels and proficiency levels. Six, texts lead learners to possess language awareness through analysis of the lexicogrammar of texts as vocabulary and grammar are connectedly used. Seventh, texts allow learners to have extensive reading as well as intensive reading. Eighth, texts release students from dependency on a textbook or teacher's directions. They have opportunities to select texts out of interest and to read them at leisure for pleasure or information. The last, textbased instruction integrates spoken and written language as in natural language use [7].

In addition, text-based teaching obliges the students to process a text before they produce their own text. This means that text-based teaching is likely to be able to meet three elements which play very important roles in English language teaching and learning, namely, input, interaction, and output. The term input in language teaching and learning was first proposed by Krashen in his theory of input hypothesis [9]. Input is spoken English texts or written ones. Input has to comprehensible (i+1), that is, the input should a bit higher than the students' present ability. Input should not be too difficult nor too easy. If it is too difficult, students will not be able to understand the text and this will not lead them to acquire some linguistic elements form the text. The text should not be too easy since if it is so, the students will get nothing as there is nothing new for the students; except if the purpose of teaching and learning is for fluency [1]. There are at least three benefits of having input for students, namely, 1) the students are exposed with linguistic elements used in context, 2) the students are exposed with how a text is organized, and 3 ) the students are provided with knowledge of the world presented in the text.

Input needs to be processed so that it is comprehensible. Long in Swain states to make input comprehensible is through interactional modification, that is, through modification to learners' input when there is a hint that the input is not comprehensible to the learners [3]. When there is an interaction in English between a learner and the teacher, or a learner and another learner, negotiation of meaning is likely to occur. This will lead to language acquisition. In other words, interaction during the teaching and learning process is of paramount importance for making input comprehensible and accordingly language acquisition takes place.

Interaction cannot automatically take place among students in a class. Teachers need to manage a class in such a way that interaction can be experienced by the the entire members of the class. Long and Porter in their article showed that small groupwork will increase students' opportunities to interact with their classmates and teacher [5]. Furthermore, Lixin's studies showed that students loved groupwork activities in class, moreover if the topics for the group discussion were related to their college life [2]. In the groupwork the learners interact one another to negotiate meaning related to topics they discuss. Leeming in his study towards students in compulsory English classes in a private university in Japan found that studying with friends led to smooth conversation, and students prefered selecting their own groups and also changing groups at some point during a single semester [6].

In addition to input and interaction, there is another thing which is also of paramount importance, namely, output. Swain refers to output as learners use the target language [3]. The target language produced by the students that forms an utterance (a spoken text) or a written text is output. Swain views producing output as a communicative activity and as a cognitive activity. Saying an utterance or writing a text is a cognitive activity, and what is said or what is written is an output. Producing output is a cognitive activity. In saying or writing, a learner will retrieve all linguitic knowledge s/he has, connect one element to another one, and think it again to make sure what $\mathrm{s} / \mathrm{he}$ expresses follows the rule of the target language. Further, Swain explains that producing texts in the target language provides the students with some benefits. Firstly, it is called as noticing function, that is. The learners realize what they do not know or only partially know. They know what they want to say but are unable to communicate it. This is done through practice, verbally communicating in the second language in the classroom. Secondly, it is as hypothesis-testing function: It is when the learner provides statement realizing that the grammar is not always correct and they receive feedback in order to improve. This enables the learners to reformulate their statements. Interaction within the classroom with teacher and peers can assist the learner to 
improve their grammar. Thirdly, output as a metalinguistic function: The learners reflect upon the language learned and this enables them to control their output and internalize their linguistic knowledge.

This article presents the results of a research which investigated: 1) what the students perceived by joining a textbased teaching and learning, 2) what problems the students faced during the text-based teaching and learning, and 3) what the students learnt at the text-based teaching and learning.

\section{METHOD}

The subjects of this study are 208 first-year tertiary students taking English as a compulsory subjects in three parallell class, that is, T2 (70 students), T7 (69 students) and T12 (69 students), selected randomly out of 16 parallell classes of the first year students of a state engineering institute in Lampung. Each of the 3 classess are intact. The students in each class are of different majors, namely, Physics, Electrical Engineering, Geodesy Engineering, Informatics Engineering, Geology, Civil Engineering, Environmental Engineering, Architecture, Geomatics Engineering, and Urban Planning Engineering.

The students took the English subject which was held for one semester consisting of 16 100-minute meetings. On the first meeting the students were asked their goal of learning English, and the goal of the English subject was then discussed with them. After that Nation's vocabulary level test (Nation, 1990) was administered to them, and the results showed that on average they knew $61 \%, 55 \%, 38 \%, 38 \%$, and $16 \%$ of the 2000, 3000, 5000, UWL, and 10000 word level respectively.

On the second meeting, the teacher explained introduced a topic of an academic text, natural disater, and explained and discussed what understanding a text was. Then, the teacher started text-based teaching: showing the title of the text, asking the students what they wanted to know from the text in English, providing the keywords, inviting the students to ask more questions based on the ke words, asking the students to read the text to find answers for their questions which had been written down by the teacher, and then asked the students what they had learnt from the text. For the preparation next three meetings, the students were grouped into ten and each of the groups was assigned to find an academic text, to write the keywords, to understand the text in order to be the expert on the text they had selected, and to be prepared to answer questions on the text asked by other groups.

On the third meeting, after the teacher reviewed the previous material, one group was asked to acte as an expert by presenting the title of the text they had chosen, keywords, and let the students from the other groups to ask questions, and answered the questions in English. After that the teacher asked questions, such as: What do you feel after reading the text?, What do you learn from the text?, What will you do after knowing that from the text?, etc, provided feedback on their performance, and asked the groups who had just presented to share the text through internet to the other groups to read thoroughly. Finally, each of the students had to write a journal led by questions prepared by the teacher. Procedures similar to this third meeting were done on the fourth and fifth meeting. The procedures of the seventh up to the sixteenth meeting were different from those of these three previous meetings, and were not included in this analysis.

The data the students' perception towards the teaching and learning were collected only from the third meeting up to the fifth meeting through observation during the teaching and learning process and through journals that the students had written in English. The data were analyzed qualitatively following the steps proposed by Miles and Huberman (1994), that is, data reduction, data display, and conclusion drawing and verification [4].

\section{FINDING AND DISCUSSION}

\section{Finding}

The research findings are grouped under three according to the objectives of the research, that is, students' perception during the implementation of the text-based teaching, Students' problems during the implementation of the textbased teaching, and linguistic elements as well as skills the students learnt in the text-based teaching and learning.

Students' perception during the implementation of the textbased teaching

Perception refers to what the students perceive, sense, feel, become aware of the state of something or someone involved in the text-based teaching and learning of English. To elicit the students' perception, $\backslash$ they were asked to answer a question: 'What did you feel when joining the English class?'. From their answer to this question, it was found that the students' perception were various, which can be grouped into four, namely, positive, negative, mixed between positive and negative, and neutral. As displayed at Table 1, most of the students $(66.1 \%)$ declared that they had positive perception toward the text-based teaching and learning, whereas the percentage of those who declared to have negative perception toward the text-based teaching and learning is much smaller, that is, $24.4 \%$, and the rest of the students showed mixed perception and neutral perception, that is, as much as, $6.5 \%$ and $2 \%$ respectively. It can be seen in the table 1 .

Table 1 The percentages of the students having positive, negative, mixed, neutral perception

\begin{tabular}{|c|c|l|l|l|l|l|l|}
\hline Class & Meeting & Topic & N & $\begin{array}{l}\text { Positi } \\
\text { ve }\end{array}$ & $\begin{array}{l}\text { Negati } \\
\text { ve }\end{array}$ & Mixed & Neutral \\
\hline \multirow{2}{*}{ T2 } & 3 & $\begin{array}{l}\text { Sexual } \\
\text { Assault }\end{array}$ & 70 & 44 & 19 & 6 & 1 \\
\cline { 2 - 8 } & 4 & $\begin{array}{l}\text { Maduka } \\
\text { Honey }\end{array}$ & 66 & 44 & 19 & 2 & 1 \\
\cline { 2 - 8 } & 5 & $\begin{array}{l}\text { Solar } \\
\text { Survival }\end{array}$ & 69 & 44 & 15 & 5 & 4 \\
\hline \multirow{2}{*}{ T7 } & 3 & $\begin{array}{l}\text { Violence } \\
\text { at School }\end{array}$ & 69 & 46 & 17 & 6 & 0 \\
\cline { 2 - 8 } & 4 & $\begin{array}{l}\text { Autism } \\
\text { Syndrom } \\
\text { e }\end{array}$ & 69 & 49 & 18 & 2 & 0 \\
\cline { 2 - 8 } & 5 & $\begin{array}{l}\text { Solar } \\
\text { Survival }\end{array}$ & 61 & 34 & 17 & 7 & 3 \\
\hline
\end{tabular}


Table 1. Cont

\begin{tabular}{|c|c|c|c|c|c|c|c|}
\hline \multicolumn{3}{|c|}{ Average } & 66 & 43 & 17 & 5 & 1 \\
\hline \multirow[t]{3}{*}{$\begin{array}{c}\mathrm{T} \\
12\end{array}$} & 3 & $\begin{array}{l}\text { Global } \\
\text { Warming }\end{array}$ & 69 & 54 & 9 & 3 & 3 \\
\hline & 4 & APEC & 65 & 41 & 14 & 8 & 2 \\
\hline & 5 & $\begin{array}{l}\text { Solar } \\
\text { Survival }\end{array}$ & 67 & 42 & 20 & 5 & 0 \\
\hline \multicolumn{3}{|c|}{ Average } & 67 & 46 & 14 & 5 & 2 \\
\hline \multicolumn{3}{|c|}{$\begin{array}{c}\text { AVERAGE GRAND } \\
\text { TOTAL }\end{array}$} & 201 & $\begin{array}{l}133 \\
(66.1 \%)\end{array}$ & $\begin{array}{l}49 \\
(24.4 \%)\end{array}$ & $\begin{array}{l}13 \\
(6.5 \%)\end{array}$ & $\begin{array}{l}5 \\
(2 \%)\end{array}$ \\
\hline
\end{tabular}

The students' perception is classified as positive when their answers consist of explicit or implicit expressions of being happy, excited, fun, getting better. Here are some data from the students' journal expressing positive perception toward the implementation of the text-based teaching and learning:

(1) I feel very happy today. You do know what? Because in class I have show up my opinion with their questions from our group.

(2) I feel interesting because at the lesson we're must can to speaking, answer a question and giving question to another team.

(3) In this class I'm feeling excited to understand what teacher says and try to speak English.

(4) I feel so happy in this class because I can teach my friend.

(5) Having this class I feel more happy than before because like what I say before I can working one job as a team not an individual.

The students' perception is classified as negative when their answer to the question contains explicit expressions or implicit ones of being unhappy following the English class. Here are some data from the students' journal expressing negative perception toward the implementation of the technique:

(6) What I feel is trembling. I feel trembling because speaking in front of the whole class. It is'nt my first but it makes me feel afraid all over again.

(7) I'm feel so bad. Because I can't be reach what I want today. I'm realize my vocab is wrong and still bad.

(8) I feel like in the other world, like a stranger. I am not Understand so many thing (words). My english is so bad. I can't speak English fluently.

(9) I feel shy to express what I feel and to express opinion in class because my English still disorganize

(10) I feel dizzy today. Especially on reading comprehension.May be the solar survivor text is very difficult to translate it.

The students' perception is classified as mixed, positive and negative, when their answer to the question contains expicit or implicit expressions of being happy and unhappy following the English class. Here are the data from the students' journal expressing this perception:

(12) I fell curious and comfused to understand the relation of one thing to another thins. but it's make me interest to find the answer, to know the topick and learn more about efect of global warming.
(13) I feel PTA its difficult for me because I don't like English Language but I curious with the English language and still willing for learnt.

(14) I feel confuse but I gradually know more about grammar.

(15) I don't have problems on lesson today, teacher explain very well, and also I listened with silence but I very bored cause teacher don't entertain like a 'ice breaking', watching video, etc.

(16) While following the lesson first I was excited, then when I started not familiar with the material I feel confused

The students' perception is classified as neutral when their answer to the question contains explicit or implicit expressions which do not show being happy or unhappy following the English class. Here are some data from the students' journal expressing neutral perception toward the implementation of the technique:

(17) I feel just so so. Like to my other learning habitual. (18) Ifelt as a lesson is usually.

Students' problems during the implementation of the textbased teaching

To find out the problems of the students joining the taskbased teaching, a question was asked to the students: What problems did you have during the teaching and learning you have just followed?. All of the students, except two, wrote one or more problems they faced during text-based teaching. Table 2 below presents the summary of the kinds of problems the students had and the number of the students who faced the problems. It can be seen in the table 2 .

Table 2 The students'problems when following the textbased teaching

\begin{tabular}{|c|r|r|r|r|r|r|r|r|r|}
\hline $\begin{array}{c}\text { Number of } \\
\text { students }\end{array}$ & \multicolumn{3}{|c|}{$\begin{array}{c}\text { T2 at } \\
\text { meeting }\end{array}$} & \multicolumn{3}{c|}{$\begin{array}{c}\text { T7 at } \\
\text { meeting }\end{array}$} & \multicolumn{3}{c|}{$\begin{array}{c}\text { T12 at } \\
\text { meeting }\end{array}$} \\
\cline { 2 - 11 } Kinds of Problems & 1 & 2 & 3 & 1 & 2 & 3 & 1 & 2 & 3 \\
\hline $\begin{array}{c}\text { Students' internal } \\
\text { traits }\end{array}$ & 8 & 8 & 8 & 4 & 2 & 3 & 3 & 3 & 4 \\
\hline Vocabulary & 28 & 28 & 28 & 25 & 26 & 16 & 28 & 29 & 24 \\
\hline Grammar & 4 & 7 & 14 & 16 & 14 & 13 & 14 & 14 & 16 \\
\hline Speaking & 31 & 30 & 30 & 35 & 35 & 35 & 30 & 32 & 30 \\
\hline Reading & 7 & 4 & 7 & 3 & 4 & 3 & 3 & 3 & 2 \\
\hline Listening & 11 & 9 & 9 & 9 & 9 & 2 & 6 & 9 & 5 \\
\hline Other students & 13 & 14 & 14 & 10 & 13 & 5 & 5 & 2 & 2 \\
\hline Sitting position & 2 & 2 & 2 & 2 & 2 & 2 & 2 & 2 & 0 \\
\hline
\end{tabular}

The first type of problem is from the students themselves, their internal traits (not confident, afraid, shy, lazy), such as expressed by the students as follows: 
(19) I still not confident with myself when I want to express my feel to speak English and I must to write first what I want to say because sometimes I feel affraid and shy when I get false.

(20) I am still shy to share my opinion.

(21) My problem in learning English is I am lazy to read an article in English.

The second type of problems faced by the students related to vocabulary mastered by the students, such as expressed by the students as follows:

(22) My problem is many word not yet understand.

(23) I have problem with vocab, speaking and my pronunciation in English. I can't remember many vocab, can't speak English fluently, my pronunciation is bad.

(24) The problem in this lesson, I think I can't translate the teacher speak very well and my vocabulary is not perfect.

The third type of problem belongs to listening problem, such as expressed by the student as follows:

(25) The problem is to fast speaking English because I not understand if speaking very fast.

(26) I guess I don't have many problem during class. Well it may difficult to understand what mom say, but sooner or later I am getting used to it.

(27) We got problem from voice, I still didn't hear from far. I fell not yet following the lesson. I had some problem from madam's voice and so fast madam teach us.

The fourth type of problems faced by the students belongs to speaking as declared by the students as follows:

(28) My problem while to learn English is less about speaking and old (long) to think.

(29) My problem is can not speak more with English.

(30) I can't found the simple words for answer the question.

The fifth type of problems possessed by the students belongs to reading as expressed by the students follows:

(31) I still can't reading and speaking use English.

(32) I still do not understand English language. I do not understand the English text identified.

(33) Sometimes I still difficult to understand the text of English

(34) The problem is I rarely to read the book, article and a movie in English.

The sixth type of problems faced by the students belongs to problems aroused by the other students as expressed by the students as follows:
(35) Existing problem such commotion. yes class was noisy in the ear. Sometimes conducive and sometime not.

(36) I think I don't have problem any more, but this class too noisy so disturbed me and the other students

The seventh type of of problems faced by the students belongs to sitting position during the text-based teaching, as expressed by the students as follows:

(37) Sit on the back seat, it's make me little bit of sleepy.

(38) I can't notice the lesson well because my group get the seat in the back. I hope the seat will be rotation every week.

(39) The chairs position, I think the position must be change because it hurts my neck.

When the students worked in a small group, each group, consisting of 5 to 10 students formed a circle. However, when the whole class presentation, the sitting position of the students was in U-formation, where on the right hand side and on the left hand side of the teacher each consisted of three ten-student rows while 2 5-6 student rows faced the the whiteboard. The students sitting on the right and on the left side had to turn their face to pay attention to the teacher or other friends who explained or presented a topic.

Linguistic elements and skills the students learnt in the textbased teaching and learning

All of the students declared in their journal that they had learnt some language aspects, skills of English, and/or knowledge of the world related to the reading topic discussed in the class. Here are some of their statements found in their journals showing what they had learnt.

The following statements written by the students in their journal show that they learnt aspects of English, such as grammar and vocabulary:

(40) In this class I have many new words and I am understand how speak in English wich right.

(41) Today I get new something by in the class today. That are example of noun phrase, gerund, number, verb III, present participle, prepositional phrase and adjective to make a sentence.

The following statements written by the students in their journal show that they learnt speaking and reading skills:

(42) I've learn many think today, such as braveness, speak out to public and present what in my mind to other group.

(43) I have learnt to speak in English, and I can make a mind map from my homework to tell about global warming and the the effect.

(44) Today I learn about how to asking someone a question and how to answer the question.

(45) We know how can we talk in front of people. We must prepare ourself before we talk to people because I have limited vocabulary. 
(46) After that I also learned about reading comprehension. We look for the main idea in the text about 'Solar Survivor'.

The following statements written by the students in their journal show that they learnt or got knowledge of the world related to the reading topics they had discussed in class.

(47) I had learnt about the sexual violence in Indonesia is need more improvement and more education to the under age girl because the under age girl is the victim.

(48) I knew how to save children who have autism. I also knew about the people who underestimate with them. And then knew how could autism happen in themshelf.

(49) We have to be good to children who have autism. They're need space to still doing their activities although they're have a special behaviour.

\section{Discussion}

The students have different perceptions when joining the text-based teaching. The students' perception is directed to the students themselves, their teacher, the other students, classroom management. Most of them have positive perception, about one-fourth have negative perception, and a few students have mixed and netral perception. The reasons why they had positive were because they had a chance to speak English, to hear English from their friends and teachers as well as, got knowledge and new vocabulary from the text discussed. They had negative perception toward the taskbased teaching because they were not confident to speak, unable to speak, and unable to understand utterances made by their teacher and the other students, and got difficulties to follow the lesson, and unable to focus on the lesson because some other students made noise.

The students declared that they had problems when joining the text-based teaching. One of the problems is from the students themselves, that is, they were not confident when speaking in public. They further said that they could not speak and difficult to express their ideas. This is likely because their spoken English proficiency is not good yet and they are not used to speaking English, moreover in front of class with a big number of students. Other problems which came from the students themselves, namely, being lazy, unorganized, and not serious. I supposed that these problems are likely not because of the text-based teaching. The problems may appear in other teaching of other subjects.

Concerning with listening problems, the students complained that they did not understand what the teacher and the other students said. Since at the beginning the students stated that they wanted to be able to speak English. The teacher told the students that she would use English most of the time when teaching, and would use Indonesian language and English when expaining the meaning of English words and grammar rule. The teacher also encouraged the students to speak English when communicating with their English teacher as well as with other students. The explanation is that they were not used to listening to English speech, and as shown before their English vocabulary size is not considered high on average. On average they knew $61 \%, 55 \%, 38 \%, 38 \%$, and $16 \%$ of the $2000,3000,5000$, UWL, and 10000 word level respectively even though there were some of the students whose vocabulary size was very good, that is, they had mastered vocabulary level 2000, 3000, 5000, and the UWL. Another explanation is that some of the students who complained being unable to understand the teacher and the other students sat at the back while the teacher and the other students did not use any speaker when speaking. This problem was coupled with the fact that in certain session the class was noisy because the expert group discussed among the members first for some time to answer the other groups'questions.

Many students complained that they had problems with English vocabulary, such as having little vocabulary, being unable to use vocabulary appropriately, forgetting words, and not understanding the meaning. Most of the problems concerning with vocabulary were likely encountered when they had spoken communication. This is confirmed with the fact that only few students declared that they had problem in reading English texts even though on average the students knew $61 \%, 55 \%, 38 \%, 38 \%$, and $16 \%$ of the 2000, 3000, 5000, UWL, and 10000 word level respectively. This is likely due to the technology which is accessible to the students for getting the meaning of the text through translation by using, for example, google translate.

It was also observed that not all of the students in the group presenting an article answered the questions asked by other groups; only some of the students in the group answered the questions. Besides that, some of the students were not able to answer the questions clearly. Sometimes, the group also took for a while to get the answer for the questions. A similar thing also happened to the the other groups who asked questions. The students who asked quetions were those who often did. The same students asked several questions while the other students did not ask any questions. This might be caused by the fact those who did not ask questions felt nervous, did not know how to ask, or their questions had been asked by the other students. Those phenomena frequently occur in English as foreign language class and need to be solved (Day, 2015) [8].

In spite of the problems they had in text-based teaching, all of the students learnt language aspects, skills of English, and/or knowledge of the world. They learnt vocabulary, grammar, speaking, and got knowledge of the world from the reading texts they had read, they became more confident to speak, and they realized what they still needed to improve their English mastery.

\section{Conclusion}

\section{CONCLUSION AND RECOMMENDATION}

Text-based teaching and learning is applicable to incorporate the students' goal and the institutional goal in a big-sized English class. In addition to pushing the students to read a text, it makes the students speak English, notice others 
speaking, learn language elements, and learn from others. Most of the students perceive text-based teaching positively. Some students who have negative perception are mainly due to their own state, such as not confident, of low English mastery, and external problems, such as sitting position, the teacher, and the other students. Even though the students have problems following the text-based teaching, they learn something, such as vocabulary, grammar, knowledge of the world, being brave to speak in front of public, and they become more aware that they still need to learn English better.

\section{Recommendation}

In order to incorporate the students' learning goal and the institutional one text-based teaching and learning has to be based on a view that text as a springboard for production. This makes the students read and also provides them a trigger to produce another text in oral forms or written forms, and at the same time it provides the students English exposure, which will be able to solve the students' lack of linguistic elements. In addition, since this study was focused on the process, further studies need to be conducted to see how much gain students are able to get from text-based teaching and learning.

\section{Acknowledgment}

This article is a revised version of the article with the same title presented orally at ISELT 2017 held by Universitas Negeri Padang (UNP). I am grateful to the committee of ISELT 2017 for accepting this paper to be included in an indexed publication.

\section{References}

[1] I.S.P. Nation and J. Newton, Teaching ESL/EFL Listening and Speaking, New York: Routledge, 2009.

[2] Lixin Xiao, "Do we reliably know what EFL students like in the English classroom at university level?," The Journal of Asia TEFL, Vol. 2, No. 3, pp. 67-94, Autumn 2005.

[3] M. Swain, "The output hypothesis and beyond: Mediating acquisition through collaborative dialoque," in Sociocultural Theory and Second Language Acquisition, J.P. Lantolf, Ed., Oxford: Oxford University Press, 2000, pp. 97-144.

[4] M.B. Miles and A.M. Huberman, Qualitative Data Analysis, Second Edition, California: Sage Publications, Inc., 1994.

[5] M.H. Long and P.A. Porter, "Group work, interlanguage talk, and second language acquisition," TESOL Quarterly, Vol. 19, No. 2, pp. 207-228, Juni 1985.

[6] P. Leeming, "Group Formation and Longevity in the Foreign Language Classroom: Students' Views", The Journal of Asia TEFL, Vol. 11, No. 3, pp 105-132, Fall 2014.

[7] P. Mickan, Text-Based Teaching: Theory and Practice, https://www.researchgate.net/publication/265011929, 2012.
[8] R. Day, "Equalizing Classroom Participation,". The Journal of Asia TEFL, Vol. 12, No.2, pp. 1-17, Summer 2015.

[9] S. Krashen, The Input Hypothesis: Issues and Implications, New York: Longman, 1985.

[10] T. Johns and F. Davies, "Text as a vehicle for Information: the classroom use of written texts in teaching reading in a foreign language," Reading in a Foreign Language. Vol. 1, No. 1, pp 1-19, March 1983.

[11] V. Marina and A. Marmiene, "Text-based language teaching and the analysis of tasks presented in English course books for students of information technology and computing," Santalka. Filologija. Edukologija, Vol. 14, No. 2, pp. 99-105, online 2006. 